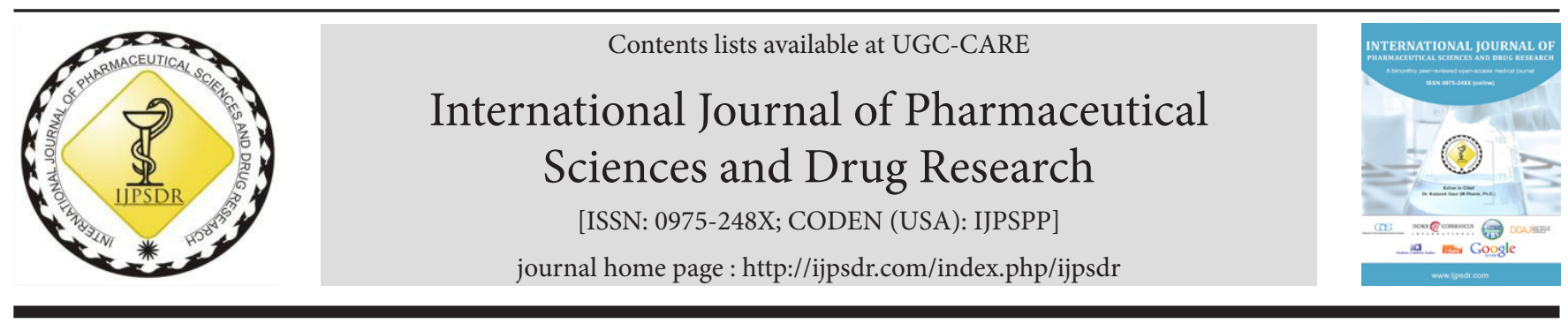

Research Article

\title{
Mechanistic Investigation on Anti-nociceptive Potential of Bartogenic Acid Containing Barringtonia racemosa Fraction in Experimental Models of Pain
}

\author{
Kalpesh R. Patil ${ }^{1}$, Umesh B. Mahajan ${ }^{1}$, Sameer N. Goyal ${ }^{2}$, Sanjay J. Surana ${ }^{3}$, Chandragouda R. Patil ${ }^{{ }^{*}}$ \\ ${ }^{1}$ Department of Pharmacology, R. C. Patel Institute of Pharmaceutical Education and Research, Shirpur-425405, Dist- Dhule, Maharashtra, India \\ ${ }^{2}$ SVKM's, Institute of Pharmacy, Dhule-424001, Maharashtra, India \\ ${ }^{3}$ Department of Pharmacognosy, R. C. Patel Institute of Pharmaceutical Education and Research, Shirpur-425405, Dist- Dhule, Maharashtra, India
}

\author{
A RT I C LE IN F O \\ Article history: \\ Received: 05 February, 2020 \\ Revised: 18 February, 2020 \\ Accepted: 23 February, 2020 \\ Published: 30 March, 2020 \\ Keywords: \\ Anti-nociceptive, Bartogenic acid, \\ Barringtonia racemosa, \\ Mechanistic study, \\ Opioid involvement, \\ TRPV1 receptor. \\ DOI: \\ 10.25004/IJPSDR.2020.120213
}

\begin{abstract}
A B S T R A C T
Barringtonia racemosa (B. racemosa) is a tropical medicinal plant possessing interesting biological activities. B. racemosa fruits are traditionally used in India for the treatment of pain, inflammation, and rheumatic conditions. Earlier, we have reported anti-inflammatory activity of ethyl acetate fraction (BREAF) obtained from B. racemosa fruits in animal models of inflammation and delayed-type hypersensitivity. The present study aimed to assess the anti-nociceptive activity of BREAF. Acetic acid-induced writhing test, and hot plate and tail immersion tests were employed to study the effect of BREAF on peripheral and central pain mechanisms, respectively. The involvement of opioid system was confirmed through naloxone antagonism. Formalin induced pain test was performed to assess the effect of BREAF on neurogenic and inflammatory pain components. Capsaicin induced pain models were used to investigate the involvement of transient receptor potential vanilloid 1 receptor. The BREAF reduced writhing episodes and delayed the onset of acetic acid-induced writhings. The raised percentage maximum protective effects by BREAF in hot plate and tail immersion tests suggest the efficacy of BREAF in pain alleviation. A reversal of the analgesic effect of BREAF following naloxone treatment indicates the involvement of opioid receptors. The BREAF also inhibited inflammatory and neurogenic components of formalin-induced pain. The inhibition of capasaicin induced pain to some extent by the BREAF indicates the possibility of involvement of TRPV1 receptors. This study reinforces the traditional use of B. racemosa in the treatment of painful conditions. However, further studies are reasonable to explore the detailed mechanism(s) of the anti-nociceptive action of BREAF.
\end{abstract}

\section{INTRODUCTION}

Barringtonia racemosa (B. racemosa) is a tropical, higher, mangrove plant species belonging to the Lecythidaceae family. ${ }^{[1]}$ Different parts of B. racemosa contain several phytoconstituents, including triterpenoids, diterpenes, saponins, alkaloids, flavonoids and tannins. ${ }^{[2]}$ Fruits of $B$. racemosa are effective in asthma and cough. ${ }^{[1]}$ Crushed kernels mixed with flour and oil are prescribed for diarrhea. In ophthalmia, aromatic seeds are applied as a collyrium in the form of thin paste prepared in cow's ghee. Seeds are effective in colic when given with milk and also used in parturition. Pulverized fruits are used as snuff, and it is applied externally along with other remedies in various skin diseases. Several traditional uses of B. racemosa leaves are control of blood pressure, relief from cough, and used as depurative. ${ }^{[3,4]}$

The various extracts of $B$. racemosa are reported to possess multiple biological activities including antibacterial activity, ${ }^{[5-7]}$ anti-fungal activity, ${ }^{[8]}$ antitumor/ chemomodulatory/anti-cancer activity, ${ }^{[9-11]}$ antioxidant

\footnotetext{
*Corresponding Author: Dr. Chandragouda R. Patil

Address: Department of Pharmacology, R. C. Patel Institute of Pharmaceutical Education and Research, Karvand Naka, Shirpur-425405, Dist-Dhule, Maharashtra, India

Email $\bowtie$ : xplore.remedies@gmail.com

Tel.: +91-9823400240

Relevant conflicts of interest/financial disclosures: The authors declare that the research was conducted in the absence of any commercial or financial relationships that could be construed as a potential conflict of interest.

Copyright (C) 2020 Kalpesh R. Patil et al. This is an open access article distributed under the terms of the Creative Commons Attribution- NonCommercialShareAlike 4.0 International License which allows others to remix, tweak, and build upon the work non-commercially, as long as the author is credited and the new creations are licensed under the identical terms.
} 
activity, ${ }^{[1,11,12]}$ anti-inflammatory activity, ${ }^{[1,13,14]}$ antiarthritic activity, ${ }^{[15]}$ analgesic activity, ${ }^{[6,16]}$ alphaglucosidase inhibitor activity, ${ }^{[17]}$ anti-mycobacterial/ anti-tuberculosis activity, ${ }^{[18]}$ anti-diarrhoeal activity, ${ }^{[6]}$ molluscicidal, cercariacidal, larvicidal, and anti-plasmodial activities. $^{[19]}$

Deraniyagala et al. 2003, evaluated aqueous bark extract $(500,750,1000$, or $1500 \mathrm{mg} / \mathrm{kg})$ of $B$. racemosa for anti-nociceptive activity using a hot plate, tail-flick, and formalin tests in male rats. ${ }^{[16]}$ Authors noted that anti-nociceptive activity of the extract was evident in hot plate and formalin test, whereas the promising results were not observed in tail-flick test. Furthermore, the anti-nociceptive activity of the extract was devoid of any side effects or toxicity. Fertility, gestational length, peri and neonatal development remain unaltered by the extracts, which suggested the non-teratogenic effect of the tested extract. The anti-nociceptive effect of $B$. racemosa bark extract was proposed to be mediated through the opioid mechanisms. This inhibition of pain was assigned to the presence of phenolic and steroidal constituents in the extract. ${ }^{[16]}$ In a combined study, carried out for antiinflammatory and analgesic activities, Shikha et al., 2010 assessed the analgesic potential of ethanolic extract of B. racemosa fruits. Administration of ethanolic extract at the oral dosage of 125,250 and $500 \mathrm{mg} / \mathrm{kg}$ showed inhibition of acetic acid evoked writhings in mice. ${ }^{[14]}$ A similar study was conducted by Saha et al. for the evaluation of the analgesic activity of ethanolic bark extracts of $B$. racemosa. Extract (250 and $500 \mathrm{mg} / \mathrm{kg}$, p.o.) exhibited dose-dependent analgesic activity by the inhibition of writhings induced by intraperitoneal administration of acetic acid. ${ }^{[6]}$ Although these studies have evaluated the analgesic activities of B. racemosa. These studies were conducted on the crude extracts at a higher dosage ranging from 250 to $1500 \mathrm{mg} / \mathrm{kg}$.

Some studies highlighted the accessibility of multiple reports pertaining to the analgesic and anti-inflammatory activities of various phytoconstituents and plant-derived products. ${ }^{[20,21]}$ However, only a few phytochemicals can succeed in the clinical trial and are available for human use. Limited data is available on the mechanism of the anti-nociceptive activity of plant-derived products. Hence, there is an intense need for systemic evaluation of antinociceptive effects of traditional medicinal plants through the use of appropriate animal models and exploration of its possible mechanism of actions for anti-nociceptive effects.

Anti-inflammatory and analgesic activities of B. racemosa, executed on the crude extracts at significantly larger dosage in selected animal models have been previously reported. ${ }^{[16]}$ In our earlier study, we noted that bartogenic acid-containing ethyl acetate fraction of $B$. racemosa fruits (BREAF) exhibits significant anti-inflammatory activity in animal models of acute, chronic, and immune inflammation. ${ }^{[13]}$ As most of the pathophysiological events and chemical mediators of pain and inflammation are common, the results of the antiinflammatory activity of BREAF prompted us to undertake the present investigation.

The present study was planned and executed to explore the probable mechanisms of the anti-nociceptive activity of the BREAF obtained from the fruits of $B$. racemosa. This study represents a methodical evaluation of BREAF in experimental models of pain. The BREAF was systematically investigated at the oral dosage of 5,10 , and $20 \mathrm{mg} / \mathrm{kg} /$ day, using judicious employment of animal models and antagonists to delineate probable mechanisms of anti-nociceptive activity of BREAF.

\section{MATERIALS AND METHODS}

\section{Chemicals and Biochemicals}

Capsaicin (M-2028-50MG; purity $\geq 95 \%$ ); Naloxone (1453005-125MG); Ruthenium Red (557450-250MG); and Fentanyl (1269902-100MG) were purchased from Sigma Aldrich, USA through its distributor in Mumbai, India. Acetic acid was obtained from Merck, India. Aspirin was purchased from local pharmacy. Other chemicals and solvents used in the extraction and fractionation were of analytical grade.

\section{Plant Material}

Fruits of Barringtonia racemosa Roxb. (Lecythidaceae) were collected from the sea coast of Konkan, Maharashtra. The taxonomist authenticated the specimen, and the specimen was deposited. An authentic marker of bartogenic acid was generously provided by Dr. Mangala Gowri, Senior Scientist, Indian Institute of Chemical Technology, Hyderabad, Telangana, India.

\section{Extraction and Isolation of BREAF}

The BREAF was isolated according to a previously reported method by Mangala et al. ${ }^{[17]}$ with some modifications. The detailed procedure for the extraction and isolation of BREAF was reported in our earlier publication. ${ }^{[13]}$ The HPTLC of triterpenoids containing fraction (BREAF) obtained from the B. racemosa fruits confirmed three spots, including one intense blue spot $\left(R_{\mathrm{f}}=0.68\right)$ approaching to bartogenic acid marker. The BREAF was subjected to LC-ESI/MS for the identification of purity and composition. ${ }^{[13]}$

\section{Experimental Animals and Drug Administration}

Swiss albino mice of either sex (22-30 g)) were used in the present study. Animals were obtained from the Committee for the Purpose of Control and Supervision of Experiments on Animals (CPCSEA) approved animal house facility. Animals were maintained in polypropylene cages at $22 \pm 2{ }^{\circ} \mathrm{C}$ with free access to water and food. Animals were fed with standard pellet feed (Nutrimix Std-1020). 
Mechanistic Investigation on Anti-nociceptive Potential of Bartogenic Acid Containing Barringtonia racemosa Fraction...

All the experimental procedures were approved by the Institutional Animal Ethics Committee (Reg. No. 651/ $\mathrm{PO} / \mathrm{ReBi} / \mathrm{S} / 02 / \mathrm{CPCSEA}$ ) established by the CPCSEA, Ministry of Environment and Forests, Government of India, constituted under PCA Act, 1960. In all the experimental models, each treatment group contained 6 animals $(n=6)$. The control group animals received suitable volumes of dosing vehicle. In all animal experiments, drug samples, including BREAF $(5,10$ and $20 \mathrm{mg} / \mathrm{kg})$ and standard drugs were orally administered as solutions of Tween-80 (5\%) in water.

\section{Anti-nociceptive Screening}

\section{Peripheral Pain Model}

\section{- Acetic Acid-induced Writhings in Mice}

Acetic acid-induced writhing test in mice was carried out using the method described by Koster et al. ${ }^{[22]}$ Swiss albino mice were selected one day prior to the test and were divided into groups of six mice each. Animals in each group were treated with BREAF $(5,10$ and $20 \mathrm{mg} / \mathrm{kg}$, p.o.) and acetylsalicylic acid (ASA) (200 mg/kg, p.o.) as a positive control group and Tween-80 as a negative control group. Following 1-hour of respective drug treatments, each mouse was administered with an intraperitoneal injection of $0.6 \%$ acetic acid $(10 \mathrm{~mL} / \mathrm{kg}) .{ }^{[23]}$ The writhing episode was indicated by stretching of at least one hind limb. The time of writhing initiation was recorded and writhing response was observed for 20 minutes after the acetic acid administration. Reduction in a number of writhings in the treated groups and standard group was compared with animals in the control group. ${ }^{[24]}$ Percentage protection against acetic acid-induced writhings was calculated using the following formula:

$$
\% \text { protection }=(\mathrm{Nc}-\mathrm{Nt} / \mathrm{Nc}) \times 100
$$

Where $\mathrm{Nc}$ and $\mathrm{Nt}$ is the number of writhings in control and test animals, respectively

\section{Central Pain Model}

\section{- Hot Plate Test in Mice}

A hot plate test was performed as described previously by Eddy and Leimbach ${ }^{[25]}$ with brief modifications. Swiss albino mice were randomly divided into different groups consisting of six mice in each. Animals were placed on a hot plate maintained at $55 \pm 1^{\circ} \mathrm{C}$, and pain responses (i.e., hind-paw licking and jumping) were observed. A time that elapsed between the placement of animals on the platform of apparatus and pain reaction was recorded as the response latency. ${ }^{[26]}$ Basal latency was measured, and cut-off time was fixed at 30 seconds to avoid skin damage. ${ }^{[23]}$ After 30 minutes, the mice were orally treated with the BREAF $(5,10$, and $20 \mathrm{mg} / \mathrm{kg}$, p.o.) or vehicle or with fentanyl $\left(0.1 \mathrm{mg} / \mathrm{kg}\right.$, i.p.). ${ }^{[26]}$ Hot plate latency was recorded at 30 and 60 minutes after treatment with the
BREAF or vehicle or fentanyl. Hot-plate latencies were then converted to a percentage of the maximal possible effect (\% MPE). ${ }^{[27]}$

$\% \mathrm{MPE}=$ (postdrug latency - basal latency) $/$ (cut-off time - basal latency) $\times 100$

\section{- Tail Immersion Test in Mice}

Tail immersion test was performed according to an earlier method described by Coelho et al. ${ }^{[28]}$ with some modifications. The distal part of the tail of animal was immersed in hot water maintained at $55 \pm 1^{\circ} \mathrm{C}^{[29]}$ Time (in seconds), the animal took to withdraw the tail clearly out of the water was taken as the reaction time to pain. A cut off time of 10 seconds was maintained at $55 \pm 1^{\circ} \mathrm{C}$ to prevent tissue damage. ${ }^{[30]}$ In this thermal test, pretreatment latencies were determined. Groups of mice $(n=6)$ were pre-treated orally with $\operatorname{BREAF}(5,10$, and $20 \mathrm{mg} / \mathrm{kg}$ ), vehicle or with fentanyl $(0.1 \mathrm{mg} / \mathrm{kg}$, i.p.). Tail withdrawal latency was recorded at 30 and 60 minutes after the treatment with BREAF or vehicle or fentanyl. Tail immersion responses of individual mice were converted to a percentage (\%) of the maximal possible effect (\% MPE), according to the following formula: ${ }^{[31]}$

$$
\begin{gathered}
\% M P E=(\text { postdrug latency }- \text { basal latency }) /(\text { cut-off } \\
\text { time }- \text { basal latency }) \times 100
\end{gathered}
$$

\section{- Mechanistic Study for the Involvement of Opioid System}

The possible involvement of opioid receptor system in the anti-nociceptive effect of BREAF was examined by previously reported method. ${ }^{[26]}$ Swiss mice were divided into various groups $(\mathrm{n}=6)$. Group 1 received (vehicle), Group 2 received (Vehicle + Naloxone, $2 \mathrm{mg} / \mathrm{kg}$, i.p.), Group 3 received (Fentanyl, $0.1 \mathrm{mg} / \mathrm{kg}$, i.p.), Group 4 received (Fentanyl, $0.1 \mathrm{mg} / \mathrm{kg}$, i.p. + Naloxone, $2 \mathrm{mg} / \mathrm{kg}$, i.p.), Group 5 received (BREAF, $20 \mathrm{mg} / \mathrm{kg}$, p.o.), and Group 6 received (BREAF, $20 \mathrm{mg} / \mathrm{kg}$, p.o. + Naloxone, $2 \mathrm{mg} / \mathrm{kg}$, i.p.). Naloxone, an opioid antagonist, was administered due to its short time-effects, 30 minutes after oral treatment with BREAF (20 mg/kg; p.o. $)^{[32]}$ and 15 minutes before treatment with fentanyl. Subsequently, the hot plate and tail immersion latencies were measured at pre-treatment, and 30 minutes (after fentanyl administration) and $60 \mathrm{~min}$ (after BREAF/vehicle administration) with the cut off time of $30 \mathrm{sec}$ and 10 seconds for hot plate and tail immersion test, respectively. ${ }^{[26]}$

\section{Formalin Induced Pain Model}

The anti-nociceptive activity of BREAF was evaluated according to the previously described methods with some modifications. ${ }^{[29]}$ Formalin solution $(25 \mu \mathrm{L}$ of $2 \% \mathrm{v} / \mathrm{v})$ was injected into the dorsal surface of the right hind paw of mice. Each mouse was immediately kept to the observation chamber. Degree of pain intensity was determined as the total time spent by the animal licking or biting the injected hind paw, measured by visual observation and a digital time-out stopwatch. The time animal spent licking the 
injected paw was counted in two different phases: from 0-5 minutes post-injection (neurogenic phase) and from 15-30 minutes post-injection (inflammatory phase). ${ }^{[33]}$ Animals in different groups were treated with vehicle, BREAF (5, 10 and $20 \mathrm{mg} / \mathrm{kg} /$ day, p.o.) or acetylsalicylic acid (ASA) (200 mg/kg, p.o.) as a standard drug, 1-hour before injection of formalin. ${ }^{[34]}$ Percentage (\%) inhibition was calculated by using the following formula: ${ }^{[35]}$

Inhibition (\%) = Reaction time (control) - Reaction time (treated)/Reaction time (control) $\times 100$

\section{Capsaicin Induced Pain Model}

Analgesic activity of BREAF in this model was evaluated as described earlier by Santos and Calixto ${ }^{[36]}$ with some modifications. Briefly, mice were treated with BREAF (5, 10 and $20 \mathrm{mg} / \mathrm{kg}$, p.o.) or vehicle, 1-hour before administration of capsaicin $(2 \mu \mathrm{g} / 25 \mu \mathrm{L}$, intraplantar $)$ in the plantar surface of the right hind paw of an individual mouse. ${ }^{[37]}$ Ruthenium red (3 mg/kg, i.p.), an unspecific transient receptor potential cation channel subfamily $\mathrm{V}$ member 1 (TRPV1) receptor blocker, were used as a positive control and administered 30 minutes before capsaicin injection. ${ }^{[38]}$ Animals were observed individually for 5 minutes following capsaicin injection. The time spent in licking injected paw was recorded and considered as an indicator of nociception. ${ }^{[39]}$

\section{Statistical Analysis}

Results are expressed as mean \pm SEM. Statistical significance of the difference in the central tendencies of treatment groups was determined by one-way ANOVA followed by Dunnett's multiple comparison test using GraphPad Prism. The $\mathrm{p}<0.05$ was considered statistically significant $\left(* \mathrm{p}<0.05,{ }^{* *} \mathrm{p}<0.01,{ }^{* * *} \mathrm{p}<0.001\right)$.

\section{RESULTS}

\section{Bartogenic Acid was a Major Constituent of BREAF}

LC-ESI-MS analysis of BREAF exhibited molecular ion peak at $m / z 517.5[\mathrm{M}-\mathrm{H}]^{-}$, conforming to the molecular formula $\mathrm{C}_{30} \mathrm{H}_{46} \mathrm{O}_{7}$. This is in tune with earlier reported data of bartogenic acid. ${ }^{[17,40-41]}$ The content of bartogenic acid in BREAF was found to be $78.57 \%$. The result of LC-ESI-MS analysis is available in our earlier publication https:// www.ncbi.nlm.nih.gov/pmc/articles/PMC5198830/figure/ fig $1{ }^{[13]}$ The HPTLC, IR and LC-MS analysis confirmed that bartogenic acid is a major component of BREAF. ${ }^{[13]}$

\section{BREAF Exhibited Anti-nociceptive Action}

\section{Acetic Acid-induced Writhings in Mice}

The results of BREAF effect in the acetic acid-induced writhing test are represented in Table 1 . The BREAF at all the tested oral doses of 5, 10, and $20 \mathrm{mg} / \mathrm{kg}$ demonstrated significant $(\mathrm{p}<0.05 ; 5 \mathrm{mg} / \mathrm{kg}$, and $\mathrm{p}<0.01 ; 10$ and 20 $\mathrm{mg} / \mathrm{kg}$ ) reduction in the total number of abdominal constrictions called writhings. Percentage (\%) protection offered by BREAF as compared with the vehicle-treated control group at the oral dosage of 5, 10, and $20 \mathrm{mg} / \mathrm{kg}$ were found to be $14.29,45.23$, and $59.52 \%$, respectively. ASA at the dose of $200 \mathrm{mg} / \mathrm{kg}$, p.o. was used as a standard drug which offered $76.19 \%$ protection through the significant $(\mathrm{p}<0.01)$ inhibition of number of writhing episodes within 20 minutes after the intraperitoneal injection of acetic acid (Table 1). The BREAF and ASA caused the significant $(\mathrm{p}<0.01)$ delay in the time of writhing initiation at the tested dosage of BREAF (10 and $20 \mathrm{mg} / \mathrm{kg}$, p.o.). However, ASA (200 mg/kg, p.o.) extended the onset of writhings up to 8.6 minutes. The effect of BREAF $(20 \mathrm{mg} / \mathrm{kg}$, p.o.) and ASA was comparable (Table 1).

\section{Hot Plate Test in Mice}

Hot plate test was used to study the effect of centrally acting analgesics in increasing the reaction time of mice in response to thermal stimuli. The BREAF exhibited a dosedependent effect against thermally induced pain in the mice. This inhibition was statistically significant $(\mathrm{p}<0.01)$ in the mice treated with BREAF at the dosage of 10 and 20 $\mathrm{mg} / \mathrm{kg}$, p.o. at 30 and 60 minutes after the oral treatments as compared with the vehicle-treated group. BREAF at a lowest dose of $5 \mathrm{mg} / \mathrm{kg}$, p.o. also showed significant ( $\mathrm{p}$ $<0.01$ ) analgesic activity at 60 minutes following drug treatment. Percentage maximal possible effect (\% MPE) of BREAF $(5,10$, and $20 \mathrm{mg} / \mathrm{kg})$ and fentanyl $(0.1 \mathrm{mg} / \mathrm{kg})$ treated mice after 30 , and 60 minutes of drug administration was represented as Table 2. Due to the transient action of Fentanyl (0.1 mg/kg, i.p.), \% MPE was decreased after 60 minutes as compared to \% MPE at 30 minutes. However, a time-dependent increase in \% MPE was observed in BREAF treated mice at all time intervals in a dose-dependent manner (Table 2).

Table 1: Effect of BREAF on acetic acid induced writhings in mice

\begin{tabular}{lll}
\hline Group & Number of writhings & Time of writhing initiation (min) \\
\hline Control & $42.0 \pm 2.2$ & $4.6 \pm 0.4$ \\
BREAF (5 mg/kg, p.o.) & $36.0 \pm 1.3^{*}(14.29 \%)$ & $5.2 \pm 0.4$ \\
BREAF (10 mg/kg, p.o.) & $23.0 \pm 1.5^{* *}(45.23 \%)$ & $7.2 \pm 0.2^{* *}$ \\
BREAF (20 mg/kg, p.o.) & $17.0 \pm 1.3^{* *}(59.52 \%)$ & $8.4 \pm 0.5^{* *}$ \\
ASA (200 mg/kg, p.o.) & $10.0 \pm 0.9^{* *}(76.19 \%)$ & $8.6 \pm 0.4^{* *}$ \\
\hline
\end{tabular}

Values represent mean \pm S.E.M. $(n=6)$. Values in parenthesis indicate percentage protection. ${ }^{*} \mathrm{p}<0.05,{ }^{* *} \mathrm{p}<0.01$, as compared with control group (One way ANOVA followed by Dunnett's multiple comparison post hoc test) 
Mechanistic Investigation on Anti-nociceptive Potential of Bartogenic Acid Containing Barringtonia racemosa Fraction...

Table 2: Effect of BREAF in hot plate test and tail immersion test in mice

\begin{tabular}{lllll}
\hline & \multicolumn{3}{l}{ \% maximal possible effect (MPE) } \\
\cline { 2 - 5 } Group & \multicolumn{3}{l}{ Hot plate test } & \multicolumn{3}{l}{ Tail immersion test } \\
\cline { 2 - 5 } & 30 mins & $60 \mathrm{mins}$ & $30 \mathrm{mins}$ & $60 \mathrm{mins}$ \\
\hline Control & $2.8 \pm 0.6$ & $3.2 \pm 0.5$ & $0.87 \pm 0.2$ & $1.0 \pm 0.2$ \\
BREAF (5 mg/kg, p.o.) & $7.6 \pm 0.7$ & $13.0 \pm 2.2^{* *}$ & $3.2 \pm 0.4$ & $6.9 \pm 0.5^{* *}$ \\
BREAF (10 mg/kg, p.o.) & $14.0 \pm 1.8^{* *}$ & $24.0 \pm 1.4^{* *}$ & $7.7 \pm 0.4^{* *}$ & $12.0 \pm 0.5^{* *}$ \\
BREAF (20 mg/kg, p.o.) & $23.0 \pm 2.8^{* *}$ & $40.0 \pm 2.2^{* *}$ & $13.0 \pm 0.9^{* *}$ & $18.0 \pm 0.4^{* *}$ \\
Fentanyl (0.1 mg/kg, i.p.) & $85.0 \pm 3.9^{* *}$ & $48.0 \pm 2.2^{* *}$ & $67.0 \pm 1.7^{* *}$ & $34.0 \pm 0.9^{* *}$ \\
\hline
\end{tabular}

Values represent mean \pm S.E.M. $n=6$ animals per group. ${ }^{* *} \mathrm{p}<0.01$ as compared with a control group (one way ANOVA followed by Dunnett's multiple comparison post hoc test).

\section{Tail Immersion Test in Mice}

As compared with the control group, oral treatment of mice with BREAF $(5,10$, and $20 \mathrm{mg} / \mathrm{kg})$ resulted in a significant enhancement of \% MPE. The anti-nociceptive effect of the higher dose (20 mg/kg, p.o.) of BREAF was superior to low and intermediate ( 5 and $10 \mathrm{mg} / \mathrm{kg}$, p.o.) dosage of BREAF. Analgesic effect of fentanyl was evident within 30 minutes after its intraperitoneal administration, followed by a successive decrease in \% MPE at 60 minutes. Analgesic activity of BREAF at all the tested doses was found to be dose-dependent (Table 2).

\section{Involvement of Opioid Pathway}

Opioid involvement in the anti-nociceptive activity of BREAF was examined by injecting a nonselective opioid receptor antagonist, naloxone hydrochloride $(2 \mathrm{mg} / \mathrm{kg}$, i.p.), 30 minutes after the oral administration of BREAF as described in material and methods section. To evaluate the involvement of opioid receptors in the anti-nociceptive effect of BREAF, it was administered in mice at the single higher dose of $20 \mathrm{mg} / \mathrm{kg}$, p.o. and evaluated through hot plate and tail immersion tests. Animals treated with the only naloxone was not displayed any significant increase in paw withdrawal latencies or tail withdrawal latencies in hot plate and tail immersion tests, respectively (Fig. 1).

\section{Formalin Induced Pain in Mice}

Administration of $\operatorname{BREAF}(5,10$, and $20 \mathrm{mg} / \mathrm{kg}$, p.o.) caused a significant change in \% inhibition of duration of paw-lickings in treated animals as compared with the control group animals at early neurogenic phase (Table 3 ). Duration of paw-licking in late inflammatory phase was lower for BREAF at the dosage of 5,10 , and $20 \mathrm{mg} / \mathrm{kg}$, p.o., as compared with paw-licking time in control group animals (Table 3 ). The group of animals treated with ASA (200 mg/kg, p.o.) spend less time in paw-licking during both neurogenic and inflammatory phase. Effect of BREAF in formalin-induced pain test in mice was in a dose-dependent manner, where the maximum activity was showed at the higher dose of $20 \mathrm{mg} / \mathrm{kg}$, p.o. as compared to the intermediate (10 mg/kg, p.o.) and lower dose (5 mg/kg, p.o.).

\section{Capsaicin Induced Pain in Mice}

To investigate the involvement of transient receptor potential vanilloid 1 (TRPV1) receptors in anti-nociceptive
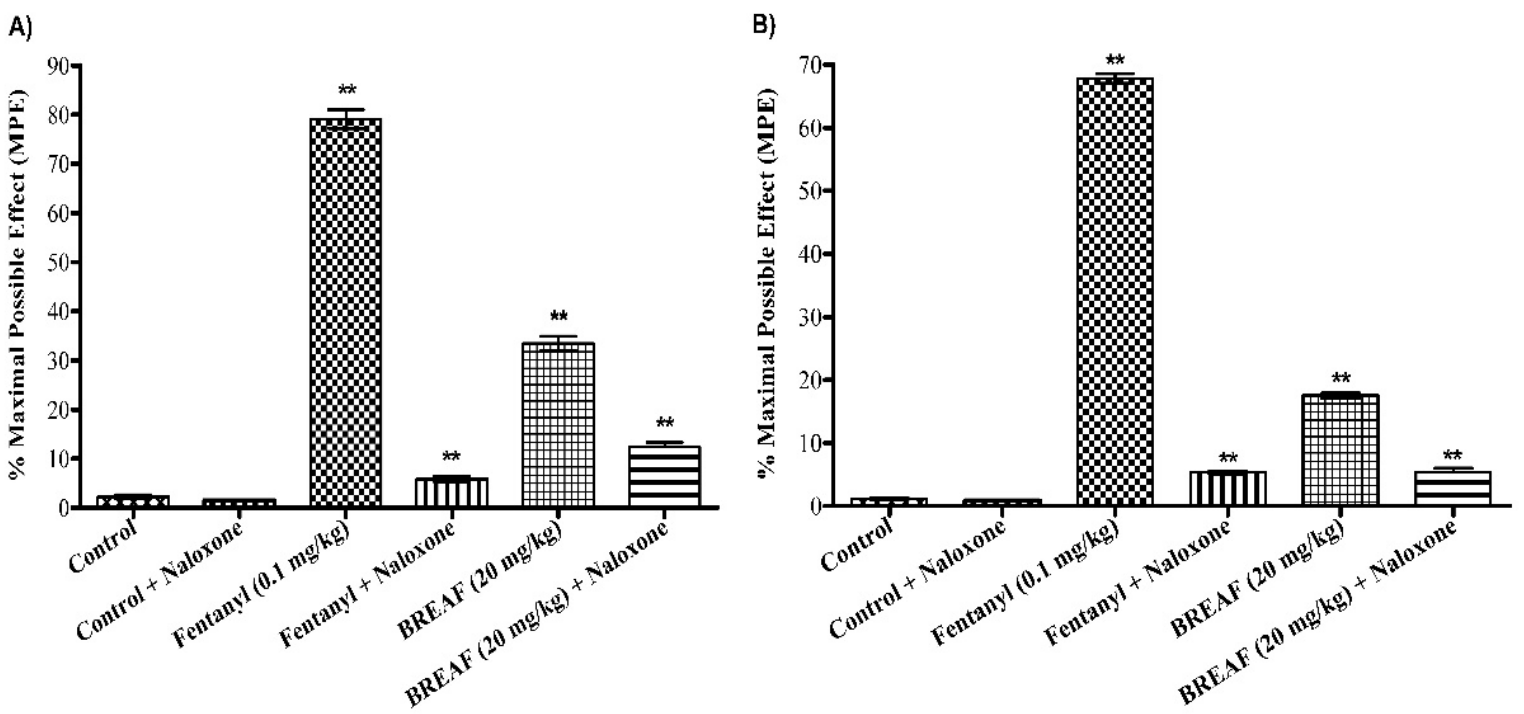

Fig. 1: Involvement of opioid receptors in the anti-nociceptive activity of BREAF; A) Reversal of anti-nociceptive effect of BREAF following naloxone treatment in hot plate test; B). Reversal of anti-nociceptive effect of BREAF following naloxone treatment in tail immersion test 
Kalpesh R. Patil et al.

Table 3: Effect of BREAF in formalin-induced pain model in mice

\begin{tabular}{lll}
\hline & Licking time (sec) & \\
\cline { 2 - 3 } Group & Neurogenic phase & Inflammatory phase \\
\hline Control & $114.0 \pm 4.7$ & $121.0 \pm 3.3$ \\
BREAF (5 mg/kg, p.o.) & $96.0 \pm 3.2^{* *}(15.78 \%)$ & $101.0 \pm 3.0^{* *}(16.52 \%)$ \\
BREAF $(10 \mathrm{mg} / \mathrm{kg}$, p.o.) & $89.0 \pm 2.7^{* *}(21.92 \%)$ & $87.0 \pm 2.0^{* *}(28.09 \%)$ \\
BREAF (20 mg/kg, p.o.) & $84.0 \pm 2.3^{* *}(26.31 \%)$ & $73.0 \pm 1.9 * *(39.66 \%)$ \\
ASA (200 mg/kg, p.o.) & $69.0 \pm 1.7^{* *}(39.47 \%)$ & $38.0 \pm 3.2^{* *}(68.59 \%)$ \\
\hline
\end{tabular}

Values represent mean \pm S.E.M. $n=6$ animals per group. Values in parenthesis represent the percentage (\%) inhibition of reaction time. ${ }^{* *} \mathrm{p}<0.01$, as compared with a control group (one way ANOVA followed by Dunnett's multiple comparison post hoc test).

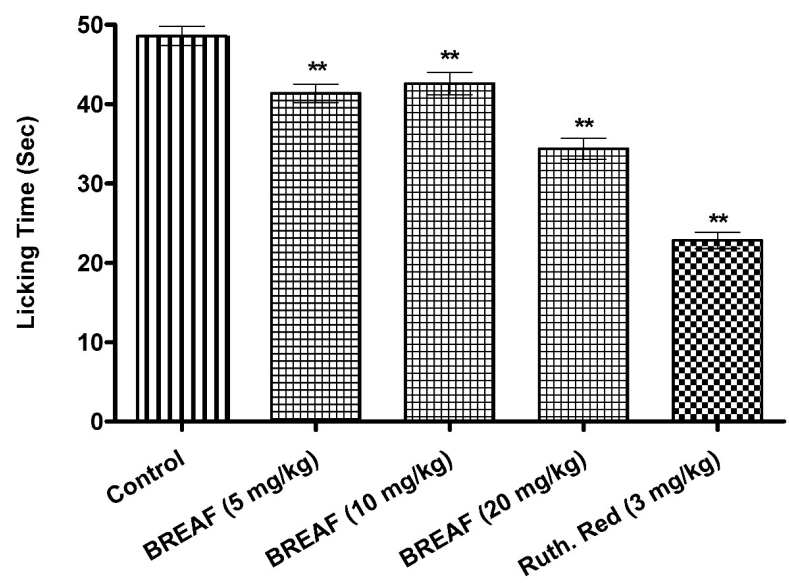

Fig. 2: Effect of BREAF in capsaicin-induced pain model. Values represent mean \pm S.E.M. ${ }^{* *} \mathrm{p}<0.01$, as compared with a control group (one way ANOVA followed by Dunnett's multiple comparison post hoc test)

effect of BREAF, the capsaicin-induced pain test in mice was performed. Results presented in Fig. 2 showed that BREAF significantly increased the pain threshold of treated animals, although the effects of BREAF was not in a dose-dependent manner. Highest activity was displayed at the dose of BREAF (20 mg/kg, p.o.). Mean paw-licking time in the group of animals treated with standard drug, ruthenium red (3 $\mathrm{mg} / \mathrm{kg}$, i.p.) was lesser, as compared with the mean paw-licking time in a control group animals (Fig. 2).

\section{DISCUSSION}

The present study evaluated the possibility of BREAF in alleviating pain. Analgesic activity of BREAF was studied through chemical or thermal stimuli-induced nociception models in mice. Effectiveness of BREAF was determined on inflammatory pain (acetic acid-induced writhing test), non-inflammatory pain (hot plate and tail immersion tests), and both types of nociception (formalin-induced paw licking test). Furthermore, the involvement of opioid pathways (through opioid antagonist) and TRPV1 channels (capsaicin-induced pain) in the anti-nociceptive activity of BREAF were also evaluated in mice.
The peripheral analgesic property of BREAF was studied by using acetic acid-induced writhing test in mice. Acetic acid causes stimulation of local peritoneal receptors, release of a variety of endogenous pain mediators and stimulation of the neurons that are involved in pain sensation. ${ }^{[23]}$ These neurons are sensitive to the actions of opioids and non-steroidal anti-inflammatory drugs (NSAIDs). ${ }^{[42]}$ Pain sensation also appears to be mediated by prostaglandin pathways, peritoneal mast cells, and acidsensing ion channels. ${ }^{[42]}$ Thus, inhibition of prostaglandin synthesis is a vital analgesic mechanism in peripheral or visceral pain. ${ }^{[42]}$ Results showed that BREAF $(5,10$, and $20 \mathrm{mg} / \mathrm{kg}$, p.o.) caused significant and dose dependent decrease in total number of writhing episodes that occurred within 20 minutes of acetic acid injection in mice. These results implies the ability of BREAF to inhibit the synthesis and/or action of prostaglandins on pain-sensing neurons. Furthermore, BREAF also postponed the time of writhings initiation in experimental animals as compared with the timings of control group animals treated with only vehicle. The anti-nociceptive effect of BREAF obtained in this experiment could be mediated by peripheral pain mechanisms or by inhibition of the prostaglandin pathway.

Hot plate and tail immersion tests were used to assess the central mechanism of BREAF in making analgesia. In both these models, the sensitization of nociceptors by sensory nerves and the participation of endogenous substances like prostaglandins are abridged..$^{[43]}$ In hot plate test, the paw of animal is very sensitive to the temperatures above $50^{\circ} \mathrm{C}$, whereas, tail immersion test is founded on the observation that opioid drugs like morphine causes selective extension of reaction time of typical tail withdrawal response in experimental animals. Increase in reaction time in response to thermal stimuli suggest the analgesic activity of test drugs. ${ }^{[43]}$ Hot plate test is a frequently used model to assess the narcotic analgesia. ${ }^{[4]}$ Tail immersion facilitates spinal reflexes against nociceptive stimuli, while the hot plate test involves higher brain functions and facilitate supraspinally organized response of the pain ${ }^{[45]}$ Results of hot plate and tail immersion tests showed that BREAF caused significant $(p<0.01)$ increase in MPE percentage at the dosage of 5, 10 and $20 \mathrm{mg} / \mathrm{kg}$, p.o. in both tests. Effect of BREAF at the dose of $5 \mathrm{mg} / \mathrm{kg}$, p.o. at 30 minutes after 
its oral administration was non-significant ( $p>0.05)$ whereas the effect of BREAF at 60 minutes after its oral administration was found to be significant ( $p<0.01$ ). It could be due to the incomplete absorption of BREAF at 30 minutes following its oral administration. Results of acetic acid-induced writhing test, hot plate test, and tail immersion test suggest that the anti-nociceptive activity of BREAF is mediated by peripheral effects on the nociceptors and through the central mechanisms. The anti-nociceptive activity of BREAF in hot plate and tail immersion tests may involve opioid system and suggested the need for the study of opioid involvement in the anti-nociceptive activity of BREAF.

In order to confirm the opioid involvement in the anti-nociceptive effects of BREAF, the mechanistic study using opioid antagonist, naloxone in hot plate, and tail immersion models were performed. BREAF was studied at a single higher dose of $20 \mathrm{mg} / \mathrm{kg}$, p.o. in these experiments. Animals were administered with Fentanyl (an opioid agonist), and BREAF (20 mg/kg, p.o.) along with or without naloxone (an opioid antagonist). As compared to the control group, standard drug fentanyl showed the highest analgesic activity among all the tested drugs. Fentanyl is a potent analgesic drug that activates $\mu$ opioid receptors. The obtained results showed that the opioid antagonist naloxone significantly antagonized the analgesic effect of standard drug fentanyl. Likewise, the analgesic effects of BREAF were also significantly reversed after the concurrent administration of naloxone; however, this reversal of the analgesic effect of BREAF was not pronounced as that of reversal of effects of fentanyl by the naloxone. Anti-nociceptive effects observed in the earlier models of hot plate and tail immersion tests, along with the findings of a mechanistic study in both these models, reinforce the concept that anti-nociceptive activity of BREAF is at least partially mediated by the activation of opioid system. ${ }^{[44]}$

Formalin induced pain model is a widely employed assay in pain research. ${ }^{[46]}$ Formalin injected into the paw of the experimental animal demonstrated a biphasic response. The first phase (0-5 minutes) is believed to result from direct stimulation of primary afferent sensory neurons. The second phase (10-15 minutes) is believed to be associated with combined effects of afferent inputs like inflammatory cytokines in the periphery and sensitization in the dorsal horn. ${ }^{[46]}$ Peripherally acting drugs only inhibit

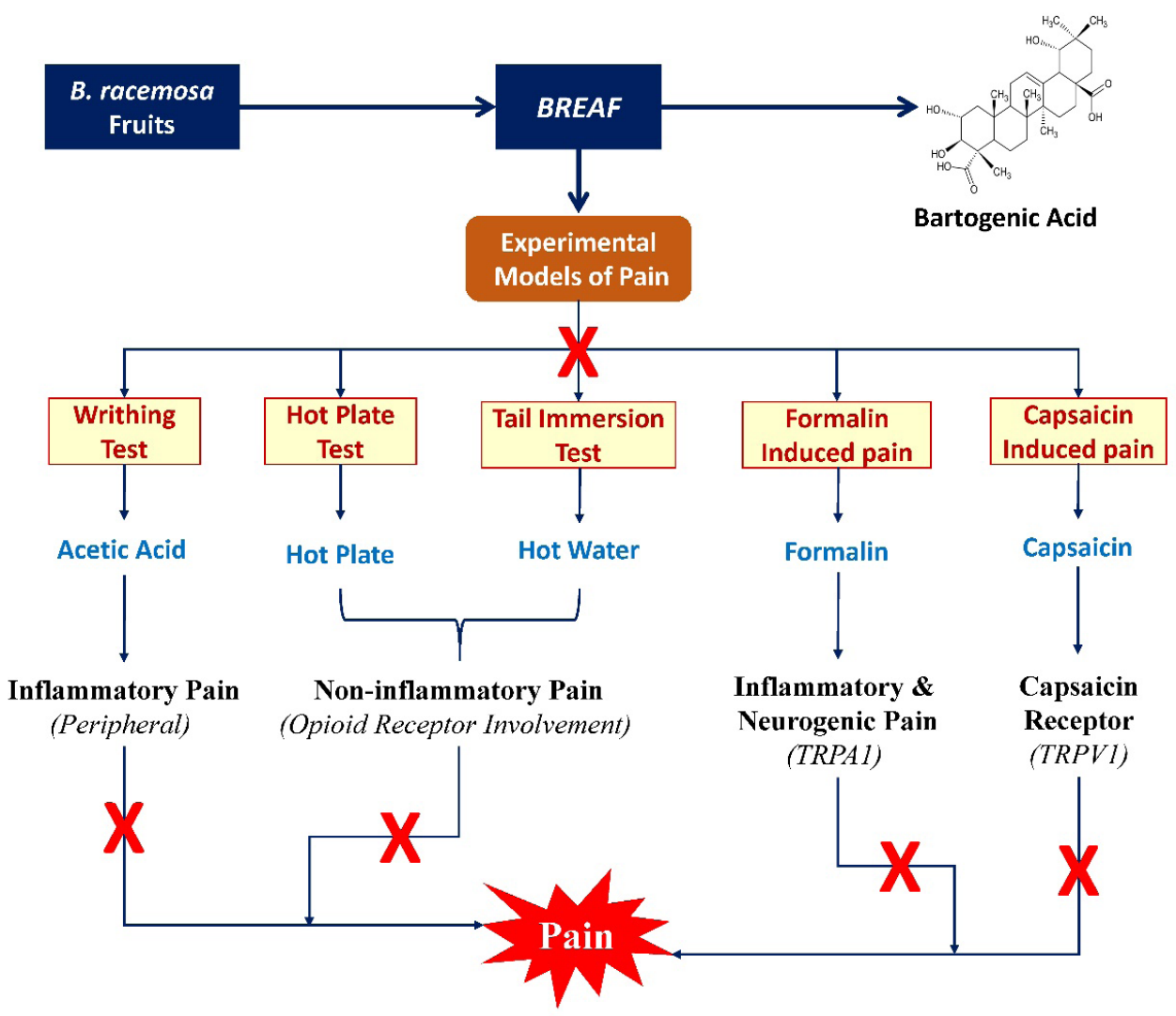

Fig. 3: Anti-nociceptive effects of BREAF in various animal models. BREAF-bartogenic acid-containing ethyl acetate fraction of $B$. racemosa fruits; TRPA1 - transient receptor potential ankyrin 1; TRPV1 - transient receptor potential cation channel subfamily V member 1; X indicate inhibition 
the second phase, while centrally acting drugs can inhibit both the phases of formalin-induced pain. ${ }^{[46]}$ Results obtained in this assay showed that BREAF suppressed both the phases of formalin-induced pain test, dosedependently, and significantly. Taken together, the results of writhing test in mice and inhibition of pain at the second (inflammatory) phase of formalin test recommend the possibility of considerable participation of inflammatory mediators in the periphery or spinal regions. The ability of BREAF to significantly alter the pain perceptions at a second (neurogenic) phase of formalin test reinforces the results of hot plate and tail immersion tests confirming the participation of central mechanisms in the antinociceptive activity of BREAF.

Transient receptor potential cation channel subfamily V member 1 (TRPV1) or capsaicin receptor represents a class of nonselective cation channels activated by capsaicin, noxious heat, protein kinase $C$, and protons. ${ }^{[47]}$ Activation of TRPV1 receptors is associated with peripheral and central pain mechanisms. Excitation of nociceptors by capsaicin encourage behavioral response such as paw licking which is effectively suppressed by vanilloid receptor antagonist, ruthenium red. ${ }^{[47]}$ Peripheral administration of capsaicin leads to molecular alterations of noxious chemical stimuli. Capsaicin causes a release of neuropeptides, excitatory amino acids, nitric oxide, and other pro-inflammatory mediators that convey the nociceptive information to the spinal cord. ${ }^{[48]}$ Results of BREAF in capsaicin-induced pain model revealed that oral treatment of mice with BREAF $(5,10$, and $20 \mathrm{mg} / \mathrm{kg})$ significantly reduced the capsaicinevoked nociceptive pain behaviors without clear doserelated effects. Administration of ruthenium red showed inhibition of capsaicin evoked pain behavior in mice. BREAF significantly decreased the neurogenic pain induced by intraplantar administration of capsaicin, similarly as in the first phase of formalin-induced pain test involving the common mechanisms. The overall effects of BREAF in various animal models are depicted as Fig. 3.

In conclusion, the findings related to the analgesic activity of BREAF include, inhibition of writhing episodes and delayed onset of writhings in acetic acid-induced pain model (peripheral analgesic activity), increased percentage maximum protective effects in both hot plate and tail immersion tests (central analgesic activity); inhibition of early (neurogenic phase) and late (inflammatory phase) phases of formalin-induced pain in mice, the involvement of opioid pathways (mechanistic study with the use of opioid antagonist naloxone in hot plate and tail immersion tests), TRPA1 ion channels (formalin induced pain model) and TRPV1 ion channels (capsaicin induced pain model).

\section{ACKNOWLEDGMENTS}

Authors are thankful to Dr. P. Mangala Gowri, Indian Institute of Chemical Technology, Hyderabad (India), for providing the sample of bartogenic acid.

\section{REFERENCES}

1. Behbahani M, Ali AM, Muse R, Mohd NB. Anti-oxidant and antiinflammatory activities of leaves of Barringtonia racemosa. Journal of Medicinal Plants Research. 2007;1(5):095-102.

2. Khan M, Omoloso A. Antibacterial, antifungal activities of Barringtonia asiatica. Fitoterapia. 2002;73(3):255-260.

3. Kong KW, Aziz AA, Razali N, Aminuddin N, Junit SM. Antioxidantrich leaf extract of Barringtonia racemosa significantly alters the in vitro expression of genes encoding enzymes that are involved in methylglyoxal degradation III. PeerJ. 2016;4:e2379.

4. Ong H, Nordiana M. Malay ethno-medico botany in Machang, Kelantan, Malaysia. Fitoterapia. 1999;70(5):502-513.

5. Khan S, Jabbar A, Hasan C, Rashid M. Antibacterial activity of Barringtonia racemosa. Fitoterapia. 2001;72(2):162-164.

6. Saha S, Sarkar KK, Hossain ML, Hossin A, Barman AK, Ahmed MI, et al. Bioactivity studies on Barringtonia racemosa (LAM.) bark. Archives. 2013;1:93-100.

7. Osman NI, Sidik NJ, Awal A. Pharmacological activities of Barringtonia racemosa L.(Putat), a tropical medicinal plant species. J Pharm Sci Res. 2015;7:185-188.

8. Hussin N, Muse R, Ahmad S, Ramli J, Mahmood M, Sulaiman MR, Shukor MY, Rahman MF, Aziz KN. Antifungal activity of extracts and phenolic compounds from Barringtonia racemosa L.(Lecythidaceae). African Journal of Biotechnology. 2009;8(12).

9. Thomas TJ, Panikkar B, Subramoniam A, Nair MK, Panikkar K. Antitumour property and toxicity of Barringtonia racemosa Roxb seed extract in mice. Journal of ethnopharmacology. 2002;82(2):223-237.

10. Patil CR, Sonara BM, Mahajan UB, Patil KR, Patil DD, Jadhav RB, Goyal SN, Ojha S. Chemomodulatory potential of bartogenic acid against DMBA/croton oil induced two-step skin carcinogenesis in mice. Journal of Cancer. 2016;7(14):2139.

11. Amran N, Rani ANA, Mahmud R, Yin KB. Antioxidant and cytotoxic effect of Barringtonia racemosa and Hibiscus sabdariffa fruit extracts in MCF-7 human breast cancer cell line. Pharmacognosy research. 2016;8(1):66.

12. Nurul Mariam H, Radzali M, Johari R, Syahida A, Maziah M. Antioxidant activities of different aerial parts of putat (Barringtonia racemosa L.). Malaysian Journal of Biochemistry and Molecular Biology. 2008;16(2):15-19.

13. Patil KR, Patil CR. Anti-inflammatory activity of bartogenic acid containing fraction of fruits of Barringtonia racemosa Roxb. in acute and chronic animal models of inflammation. Journal of traditional and complementary medicine. 2017;7(1):86-93.

14. Shikha P, Latha PG, Suja SR, Anuja GI, Shyamal S, Shine VJ, Sini S, Krishnakumar NM, Rajasekharan S. Anti-inflammatory and analgesic activity of Barringtonia racemosa Roxb. fruits. Indian J Nat Prod. 2010;1(3):356-361.

15. Patil KR, Patil CR, Jadhav RB, Mahajan VK, Patil PR, Gaikwad PS. Anti-arthritic activity of bartogenic acid isolated from fruits of Barringtonia racemosa Roxb.(Lecythidaceae). Evidence-Based Complementary and Alternative Medicine. 2011;2011.

16. Deraniyagala S, Ratnasooriya W, Goonasekara C. Anti-nociceptive effect and toxicological study of the aqueous bark extract of Barringtonia racemosa on rats. Journal of ethnopharmacology. 2003;86(1):21-26.

17. Gowri PM, Tiwari AK, Ali AZ, Rao JM. Inhibition of $\alpha$-glucosidase and amylase by bartogenic acid isolated from Barringtonia racemosa Roxb. seeds. Phytotherapy Research. 2007;21(8):796-799.

18. Mmushi T, Masoko P, Mde L, Mokgotho M, Mampuru L, Howard R. Antimycobacterial evaluation of fifteen medicinal plants in South Africa. African Journal of Traditional, Complementary and Alternative Medicines. 2010;7(1):34-39.

19. O Ojewole JA, Nundkumar N, O Adewunmi C. Molluscicidal, cercariacidal, larvicidal and antiplasmodial properties of barringtonia racemosa fruit and seed extracts. Boletín Latinoamericano y del Caribe de Plantas Medicinales y Aromáticas. 2004;3(5):88-92. 
Mechanistic Investigation on Anti-nociceptive Potential of Bartogenic Acid Containing Barringtonia racemosa Fraction...

20. Bellik Y, Boukraâ L, Alzahrani HA, Bakhotmah BA, Abdellah F, Hammoudi SM, et al. Molecular mechanism underlying antiinflammatory and anti-allergic activities of phytochemicals: an update. Molecules. 2013;18(1):322-353.

21. Abubakar A, Nazifi AB, Odoma S, Shehu S, Danjuma NM. Antinociceptive activity of methanol extract of Chlorophytum alismifolium tubers in murine model of pain: Possible involvement of $\alpha 2$-adrenergic receptor and KATP channels. Journal of Traditional and Complementary Medicine. 2020;10(1):1-6.

22. Koster R. Acetic acid for analgesic screening. In Fed proc; 1959;18:412.

23. Olonode ET, Aderibigbe AO, Bakre AG. Anti-nociceptive activity of the crude extract of Myrianthus arboreus P. Beauv (Cecropiaceae) in mice. Journal of Ethnopharmacology. 2015;171:94-98.

24. Faujdar S, Sharma S, Sati B, Pathak A, Paliwal SK. Comparative analysis of analgesic and anti-inflammatory activity of bark and leaves of Acacia ferruginea DC. Beni-Suef University Journal of Basic and Applied Sciences. 2016;5(1):70-78.

25. Eddy NB, Leimbach D. Synthetic analgesics. II. Dithienylbutenyl-and dithienylbutylamines. Journal of Pharmacology and Experimental Therapeutics. 1953;107(3):385-933.

26. Rejón-Orantes JC, Suarez DP, Rejón-Rodríguez A, Hernandez SH, Lievano OG, Rodriguez DL, et al. Aqueous root extracts from Mimosa albida Humb. \& Bonpl. ex Willd display anti-nociceptive activity in mice. Journal of Ethnopharmacology. 2013;149(2): 522-526.

27. Souza GV, Simas AS, Bastos-Pereira AL, Frois GR, Ribas JL, Verdan $\mathrm{MH}$, et al. Anti-nociceptive activity of the ethanolic extract, fractions, and aggregatin D isolated from Sinningia aggregata tubers. PloS one. 2015;10(2):e0117501.

28. Coelho LP, Reis PA, de Castro FL, Gayer CR, da Silva Lopes C, e Silva MC, et al. Anti-nociceptive properties of ethanolic extract and fractions of Pterodon pubescens Benth. seeds. Journal of ethnopharmacology. 2005;98(1):109-116.

29. Adeoluwa OA, Aderibigbe AO, Olonode ET. Anti-nociceptive property of Olax subscorpioidea Oliv (Olacaceae) extract in mice. Journal of ethnopharmacology. 2014;156:353-357.

30. Bose A, Mondal S, Gupta JK, Ghosh T, Dash GK, Si S. Analgesic, anti-inflammatory and antipyretic activities of the ethanolic extract and its fractions of Cleome rutidosperma. Fitoterapia. 2007;78(7):515-520.

31. Moniruzzaman M, Imam MZ. Evaluation of anti-nociceptive effect of methanolic extract of leaves of Crataeva nurvala Buch.-Ham. BMC complementary and alternative medicine. 2014;14(1):354.

32. Moniruzzaman M, Khatun A, Imam MZ. Evaluation of antinociceptive activity of ethanol extract of leaves of Adenanthera pavonina. Evidence-Based Complementary and Alternative Medicine. 2015;2015.

33. Imam MZ, Sumi CD. Evaluation of anti-nociceptive activity of hydromethanol extract of Cyperus rotundus in mice. BMC complementary and alternative medicine. 2014;14(1):83.

34. Luchese C, Prigol M, Acker CI, Nogueira CW. Anti-nociceptive effect of butyl (2-phenylethynyl) selenide on formalin test in mice: Evidences for the involvement of serotonergic and adenosinergic systems. European journal of pharmacology. 2010;644(1):49-54.

35. Xu Q, Wang Y, Guo S, Shen Z, Wang Y, Yang L. Anti-inflammatory and analgesic activity of aqueous extract of Flos populi. Journal of ethnopharmacology. 2014;152(3):540-545.

36. Santos A, Calixto J. Further evidence for the involvement of tachykinin receptor subtypes in formalin and capsaicin models of pain in mice. Neuropeptides. 1997;31(4):381-389.

37. Patel RB, Pawar VD, Prajapati KD, Sonara BM, Deshpande SS, Shah GB, et al. Anti-nociceptive and anti-allodynic activity of aliskiren in various pain models. European journal of pharmacology. 2013;708(1):80-7.

38. Rodrigues MR, Kanazawa LK, das Neves TL, da Silva CF, Horst $\mathrm{H}$, Pizzolatti MG, et al. Anti-nociceptive and anti-inflammatory potential of extract and isolated compounds from the leaves of Salvia officinalis in mice. Journal of ethnopharmacology. 2012;139(2):519-526.

39. Santos CA, Santos DS, Santana DG, Thomazzi SM. Evaluation of mechanisms involved in the antinociception of the ethanol extract from the inner bark of Caesalpinia pyramidalis in mice. Journal of Ethnopharmacology. 2013;148(1):205-209.

40. Arramon G, Saucier C, Colombani D, Glories Y. Identification of triterpene saponins in Quercus robur L. and Q. petraea Liebl. heartwood by LC-ESI/MS and NMR. Phytochemical Analysis. 2002;13(6):305-310.

41. Rao GS, Prasanna S, Kumar VS, Mallavarapu GR. Bartogenic acid, a new triterpene acid from Barringtonia speciosa. Phytochemistry. 1981;20(2):333-334.

42. Dina TA, Rahman MA, Ahmed NU, Uddin MN. Analgesic and antiinflammatory properties of Argyreia argentea methanol extract in animal model. Journal of Taibah University for Science. 2010;3:1-7.

43. Ezeja M, Omeh Y, Ezeigbo I, Ekechukwu A. Evaluation of the analgesic activity of the methanolic stem bark extract of Dialium guineense (wild). Annals of Medical and Health Sciences Research. 2011;1(1):55-62.

44. Ganeshpurkar A, Rai G. Experimental evaluation of analgesic and anti-inflammatory potential of Oyster mushroom Pleurotus florida. Indian Journal of Pharmacology. 2013;45(1):66.

45. Arslan R, Bektas N. Evaluation of the Centrally-Acting Mechanisms of Some Non-Steroidal Anti-inflammatory Drugs. Americal Journal of Pharmacy and Health Research. 2015;3(6):190-202.

46. Yin Z-Y, Li L, Chu S-S, Sun Q, Ma Z-L, Gu X-P. Anti-nociceptive effects of dehydrocorydaline in mouse models of inflammatory pain involve the opioid receptor and inflammatory cytokines. Scientific Reports. 2016;6:27129.

47. Oliveira FA, Costa CL, Chaves MH, Almeida FR, Cavalcante ÍJ, Lima $\mathrm{AF}$, et al. Attenuation of capsaicin-induced acute and visceral nociceptive pain by $\alpha$-and $\beta$-amyrin, a triterpene mixture isolated from Protium heptaphyllum resin in mice. Life Sciences. 2005;77(23):2942-52.

48. Spindola HM, Vendramini-Costa DB, Rodrigues MT, Foglio MA, Pilli RA, Carvalho JE. The anti-nociceptive activity of harmicine on chemical-induced neurogenic and inflammatory pain models in mice. Pharmacology Biochemistry and Behavior. 2012;102(1): 133-138.

HOW TO CITE THIS ARTICLE: Patil KR, Mahajan UB, Goyal SN, Surana SJ, Patil CR. Mechanistic investigation on anti-nociceptive potential of bartogenic acid containing Barringtonia racemosa fraction in experimental models of pain. Int. J. Pharm. Sci. Drug Res. 2020;12(2):181-189. D0I: 10.25004/ IJPSDR.2020.120213 